\title{
USE OF PLANT BIOMASS FOR REMOVAL OF MALACHITE GREEN FROM AQUEOUS SOLUTION AND OPTIMIZATION USING CENTRAL COMPOSITE DESIGN (CCD)
}

\author{
P. Pallavi1 ${ }^{1,}$, P. King ${ }^{2}$ and Y. Prasanna Kumar ${ }^{3}$ \\ ${ }^{1}$ Department of Civil Engineering, JBIT, Hyderabad-500085, (Telangana) India \\ ${ }^{2}$ Department of Chemical Engineering, Andhra University, \\ Visakhapatnam-530003, (Andhra Pradesh) India \\ ${ }^{3}$ Visakha Institute of Engineering \& Technology, Visakhapatnam, India \\ *E-mail :pallavichemico@gmail.com
}

\begin{abstract}
Biosorption is the attractive technique of wastewater treatment to retain the dyes. Biosorption of Malachite Green (MG) using leaf biomass Plumbago Zeylanica (PZ) from an aqueous solution was studied using the batch technique. The batch analysis was accessed by altering the variables like time, $\mathrm{pH}$, dye concentration, biosorbent dosage, average biosorbent size and temperature. The \% removal of $93 \%$ was attained at $25 \mathrm{mg} / \mathrm{L}$ of concentration for $50 \mathrm{ml}$ of an aqueous solution with a time of $45 \mathrm{~min}, \mathrm{pH} 9$, the dosage of $0.1 \mathrm{~g}$ and average biosorbent size of $63 \mu \mathrm{m}$ having $303 \mathrm{~K}$ as temperature. By utilizing four models the equilibrium data were reviewed. The Langmuir model was the best fit with an $\mathrm{R}^{2}$ value of 0.998 . The kinetics data were evaluated by three models. The data was suitable to Pseudo-second order kinetics. Thermodynamic parameters evaluated are enthalpy change $\left(\Delta \mathrm{H}^{\circ}\right)$, entropy change $\left(\Delta \mathrm{S}^{\circ}\right)$ and free energy $\left(\Delta \mathrm{G}^{\circ}\right)$. The negative value of $\left(\Delta \mathrm{H}^{\circ}\right)$ represents an exothermic reaction. The operating conditions are optimized using Response Surface Methodology (RSM)
\end{abstract}

Keywords: Plumbago Zeylancia, Malachite Green, Biosorption, Isotherms, Kinetics, Response Surface Methodology.

(c) RASĀYAN. All rights reserved

\section{INTRODUCTION}

In industries like food, paper, plastics, cosmetics, papermaking and textile, dyeing products. The drinking water contains traces of colored effluents that are initially mixed with water bodies ${ }^{1}$. The dye effluents from several industries are affecting the aquatic life. Transportation of suns rays into the water bodies and affecting the creative nature which reduces the photosynthetic activity by dyes.

The surroundings are polluted by discharging high concentrated effluent from the textile industry. The complex structure of dyes cannot easily biodegrade. The dye effluents should be treated to prescribed limits before final disposal ${ }^{1,2}$.

Malachite green (MG) was classified as a triarylmethane dye. MG is used for dyeing purpose. MG is used in aquaculture to regulate the fish disease and it is used as a fungicide and parasiticide also. MG is applied in the cloth, leather and acrylic industries and also broadly operated in the aquaculture as a biocide to control infections of fish ${ }^{3,4}$. When $\mathrm{MG}$ in the freshwater, the fish display a toxic disorder causing the mammalian cells toxic in nature and further affect the different body parts of fish. In humans, gastrointestinal irritation and irritation to the respiration if inhaled is caused. When MG exposed to the skin it results in tenderness and pain; simultaneous contact with eye causes permanent injury of human eyes ${ }^{5}$.

Many systems like chemical precipitation, membrane filtration are feasible for the effective discharge of MG from aquatic water bodies which are not profitable ${ }^{6}$. Studies have been done for the dye removal by using biosorption technique and selecting an eco-friendly biosorbent. The study to investigate how plumbago zeylanica was capable to remove the Malachite green in the water bodies was undertaken. The biosorption performance of Plumbago Zeylanica on various parameters was conducted and evaluated 
using equilibrium isotherm and kinetic data. The independent variables like time, $\mathrm{pH}$, dye concentration, temperature were under ideal conditions and optimized by CCD.

\section{Preparation of the Biosorbent}

\section{EXPERIMENTAL}

The leaves of Plumbago Zeylancia were taken from the garden of VEC, Guntur,. The leaves were washed with deionized water thoroughly so as to get rid of dirt and impurities. Using a domestic mixer grinder the leaves were powdered. The leave powder in the range of particle size 63(240mesh) -212 (72 mesh) $\mu \mathrm{m}$ is used directly without any pre-treatment.

\section{Batch Biosorption Procedure}

The batch studies were preceded in $250 \mathrm{ml}$ glass-stoppered flasks with a working solution of $50 \mathrm{ml}$ having $25 \mathrm{mg} \mathrm{L}^{-1}$ concentration. A quantity $(0.1 \mathrm{~g})$ of biosorbent was added to the solution. At a constant agitation of $180 \mathrm{rpm}$, the solution was rotated in an orbital shaker by maintaining the optimal $\mathrm{pH}$ required at a temperature of $303 \mathrm{~K}$ for equilibrium contact time. At the equilibrium, the samples were centrifuged, filtered and interpreted for dye concentration. Similar studies were conducted for different process parameters. The influence of biosorbent size $(63-212 \mu \mathrm{m}), \mathrm{pH}$, dye concentration, biosorbent dosage, time interval and temperature were evaluated during this study. The dye concentrations were measured using UV spectrophotometer (665 nm).

At particular time intervals, the agitated dye solutions were possessed and evaluated. The dye adsorbed per unit is:

Dye uptake, $\boldsymbol{q}_{\boldsymbol{t}}=\left(\boldsymbol{C}_{\boldsymbol{i}}-\boldsymbol{C}_{\boldsymbol{f}}\right) * \mathrm{~V} / \mathrm{w}$

Where $\mathrm{q}_{\mathrm{t}}$ is the dye uptake, $\mathrm{C}_{\mathrm{i}}$ is the initial concentration of dye, $\mathrm{C}_{\mathrm{f}}$ is the final concentration of the dye, $\mathrm{V}$ is the volume of solution, $\mathrm{w}$ is the biosorbent dosage

The percent biosorption (\%) of dye:

$\%$ Biosorption $=\left[\left(\mathrm{C}_{\mathrm{i}}-\mathrm{C}_{\mathrm{f}}\right) \times 100\right] / \mathrm{C}_{\mathrm{i}}$

\section{Experimental Design}

The present work was to optimal the parameters for biosorption of MG dye onto Plumbago Zeylancia biosorbent using RSM. 26 runs were observed twice to optimal the parameters: time, $\mathrm{pH}$, dye concentration and temperature.

\section{Equilibrium, Kinetics and Thermodynamic Studies}

The data was reviewed using Langmuir, Freundlich, Temkin and Dubbinine-Radushkevich (D-R) isotherms. Pseudo- first order, pseudo-second order and elovich models are used to design kinetics data. Thermodynamic studies give an idea whether gains or losses occur to system energy.

\section{Effect of Contact Time}

\section{RESULTS AND DISCUSSION}

With respect to contact time, the \% biosorption of MG dye on PZ biosorbent was represented in Fig.1. For a time period of 5 to $45 \mathrm{~min}$, a number of free surface sites is applicable for biosorption and as time period increases, the surface sites are employed with the dye molecules ${ }^{7,8}$. In Fig 1, an equilibrium site which is attained at $45 \mathrm{~min}$ where biosorption will not alter with contact time and remained plateau is represented at a dye concentration of $25 \mathrm{mg} / \mathrm{L}$. The biosorption efficiency is increased from $81.96 \%$ to $93 \%$ with a contact time of $45 \mathrm{~min}$ at $25 \mathrm{mg} / \mathrm{L}$ dye concentration.

\section{Effect of Solution pH}

MG in aqueous solution contains positively charged ions. For charged species, the degree of biosorption onto the biosorbent surface is mainly altered by the biosorbent, which consecutively has an impact on $\mathrm{pH}$ 
9. Fig. 2 represents the effect of $\mathrm{pH}$ on the biosorption of dye, where the $\mathrm{MG}$ removal increased with an increase in $\mathrm{pH}$. The biosorption efficiency is influenced by the $\mathrm{H}^{+}$concentration ${ }^{10}$. As surface density decrease with an increment in the $\mathrm{pH}$, the electrostatic repulsion between the positively charged $\mathrm{MG}$ and the surface of the PZ is low, that conclude that biosorption rate increases. 93\% of maximum biosorption was obtained at $\mathrm{pH} 9$.

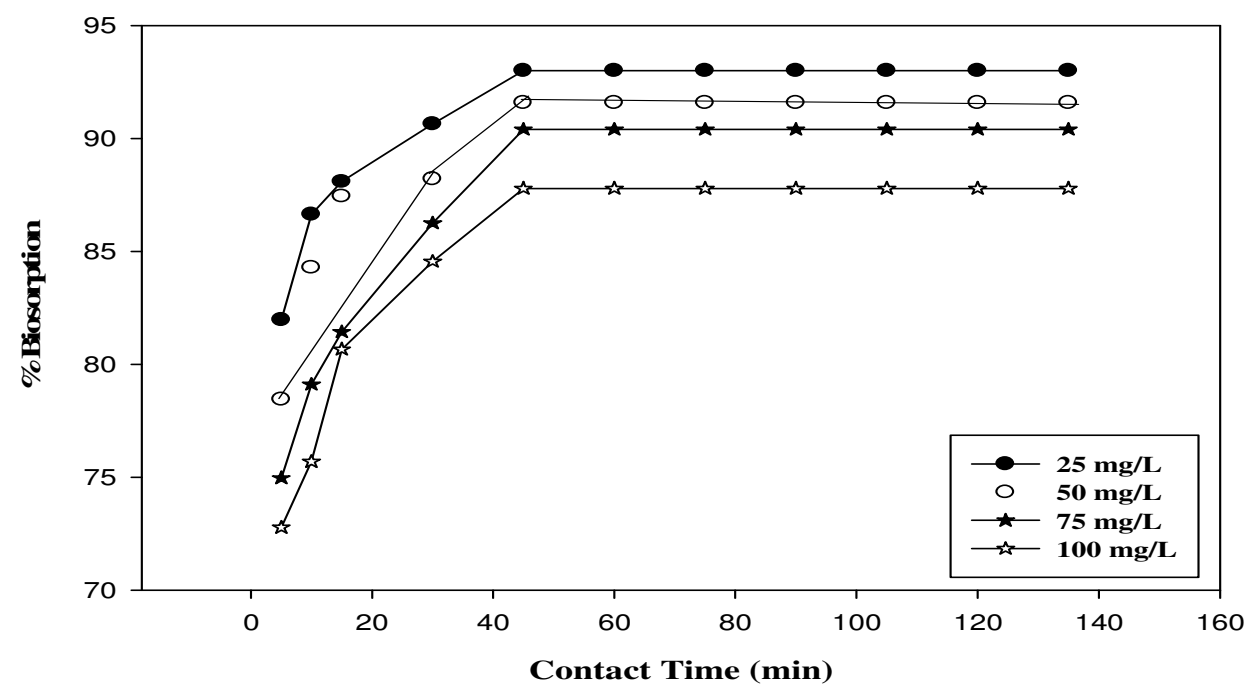

Fig.-1: Contact time its effect on biosorption of MG dye by Plumbago Zeylancia

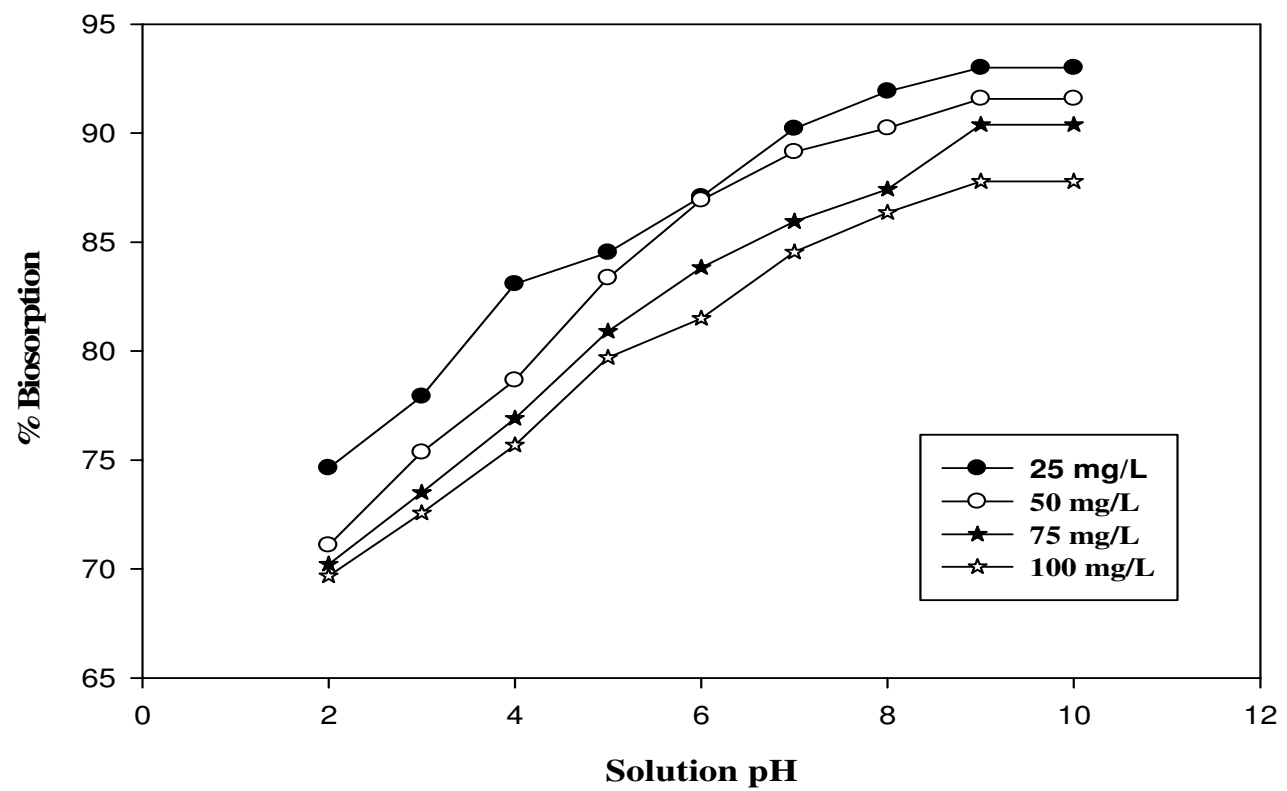

Fig.-2: Solution pH effect on biosorption of MG dye by Plumbago Zeylancia

\section{Effect of Dye Concentration}

The biosorption rate is an objective of the concentration of the biosorbate, representing effective biosorption. The impacts of different concentrations are in the range of $25-100 \mathrm{mg} / \mathrm{L}$ on the biosorption of MG onto Plumbago Zeylancia. With an increment in dye concentration, the \% biosorption was declined and dye uptake was inclined (Fig.3). At 303K, the dye uptake increased from 11.62 to 43.89 $\mathrm{mg} / \mathrm{g}$ and \% biosorption of dye concentration decreased from 93 to $87.78 \%$. 
RASĀYAN J. Chem.

Vol. 11 | No. 1 |203-218 | January - March | 2018

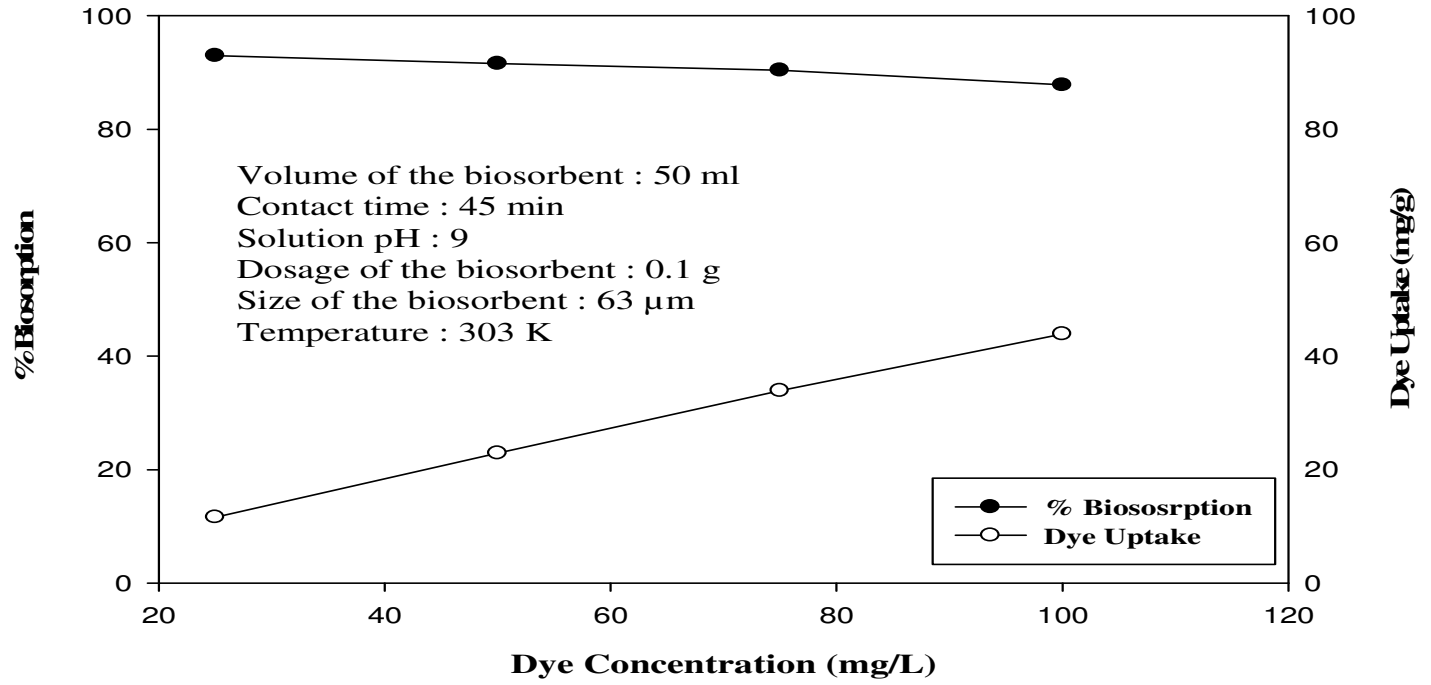

Fig.-3: Concentration and its effect on biosorption of MG dye by Plumbago Zeylancia

\section{Effect of Dosage of Biosorbent}

The dosage of biosorbent influences the process of biosorption. Therefore the impact of biosorbate dosage on MG biosorption was identified in the range of $0.02-0.2 \mathrm{~g}$. The $\%$ biosorption increased with an increment of dosage and attains equilibrium at $0.1 \mathrm{~g}$. Fig- 4 shows that $\%$ biosorption increases with increasing biosorbent dosage for MG concentration $(25 \mathrm{mg} / \mathrm{L})$, more dosage will indicate more availability of biosorption sites and more will be the MG adsorbed ${ }^{11}$. For $0.02-0.2 \mathrm{~g}$ of increment in biosorbent dosage the percentage removal was increased from $78.6 \%$ to $93 \%$ at $25 \mathrm{mg} / \mathrm{L}$ of dye concentration.

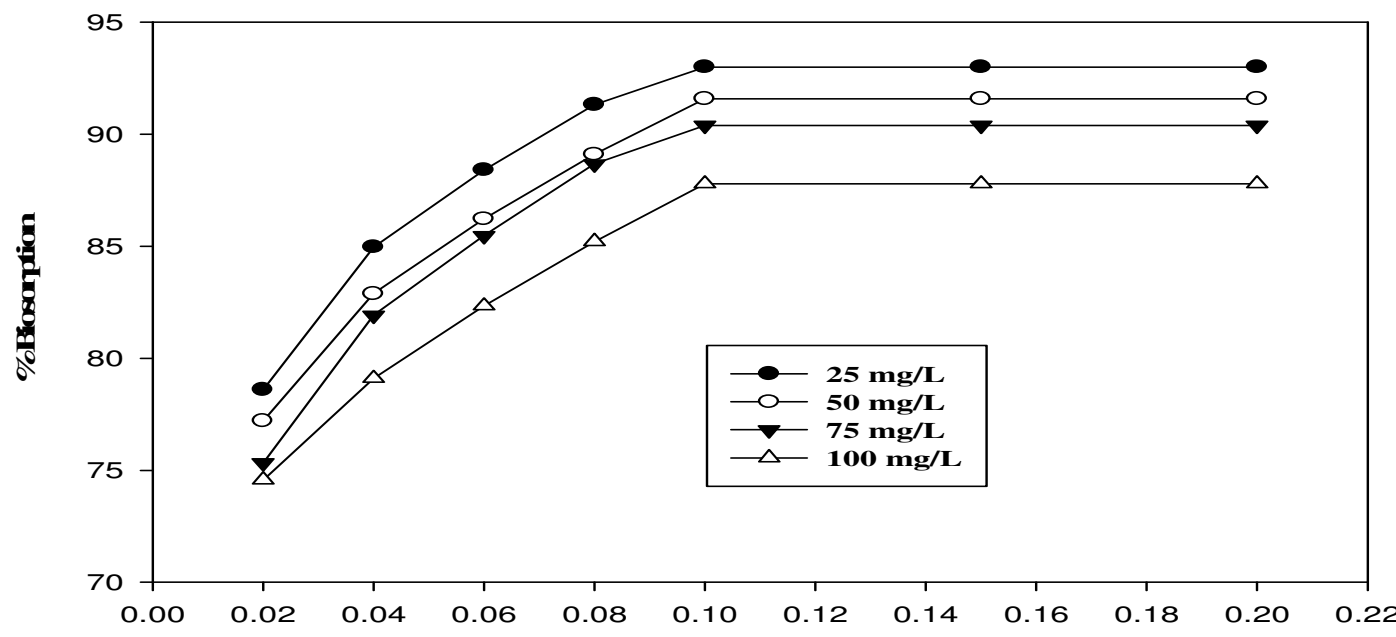

Biosorbent Dosage (g)

Fig.-4: Effect of biosorbent dosage on biosorption of MG dye by Plumbago Zeylancia.

\section{Effect of Biosorbent Size}

The effect of biosorbent size for a range of 63(240 mesh) $\mu \mathrm{m}$ to 212 (72mesh) $\mu \mathrm{m}$ was studied. Fig.5 shows the decline in percentage biosorption with an increase in particle size, because the higher surface area for smaller particles with an increase of binding sites, which indicates that rapid sorption and high mass transfer compared to larger particles that were used ${ }^{12}$. Therefore, $\%$ biosorption decreased from $93 \%$ to $74.2 \%$ at $25 \mathrm{mg} / \mathrm{L}$ of dye concentration. 
RASĀYAN J. Chem.

Vol. 11 | No. 1 |203-218 | January - March | 2018

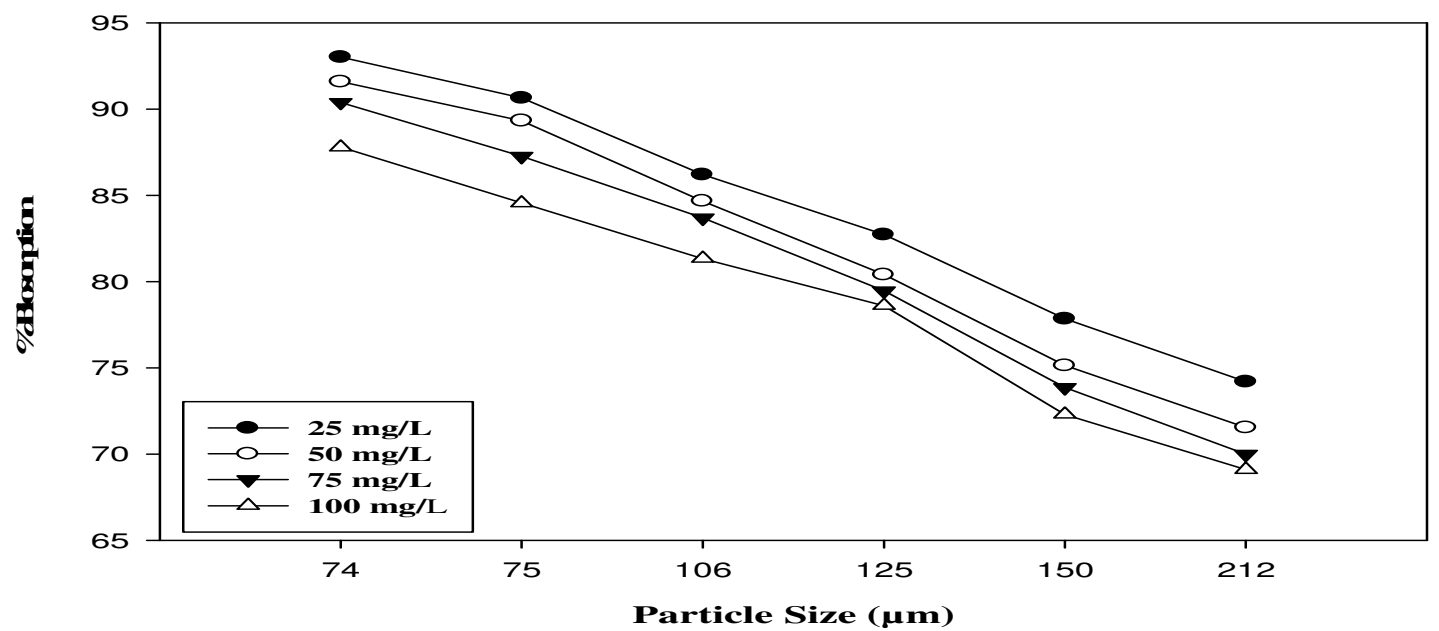

\section{Effect of Temperature}

Fig.-5: Particle size effect on biosorption of MG dye by Plumbago Zeylancia

The temperature affects the biosorption capacity of the dye. Batch experiments of biosorption were performed at a temperature varying from $303 \mathrm{~K}$ to $343 \mathrm{~K}$. Fig. 6 shows a decrease in percentage biosorption with an increment in temperature. With an increase in temperature, the density decreases as dye transfer from the biosorbent surface to the solution phase ${ }^{13}$. The maximal biosorption is seen at $93 \%$ for a time interval of $45 \mathrm{~min}$ at $303 \mathrm{~K}$ temperature, having $25 \mathrm{mg} / \mathrm{L}$ of dye concentration.

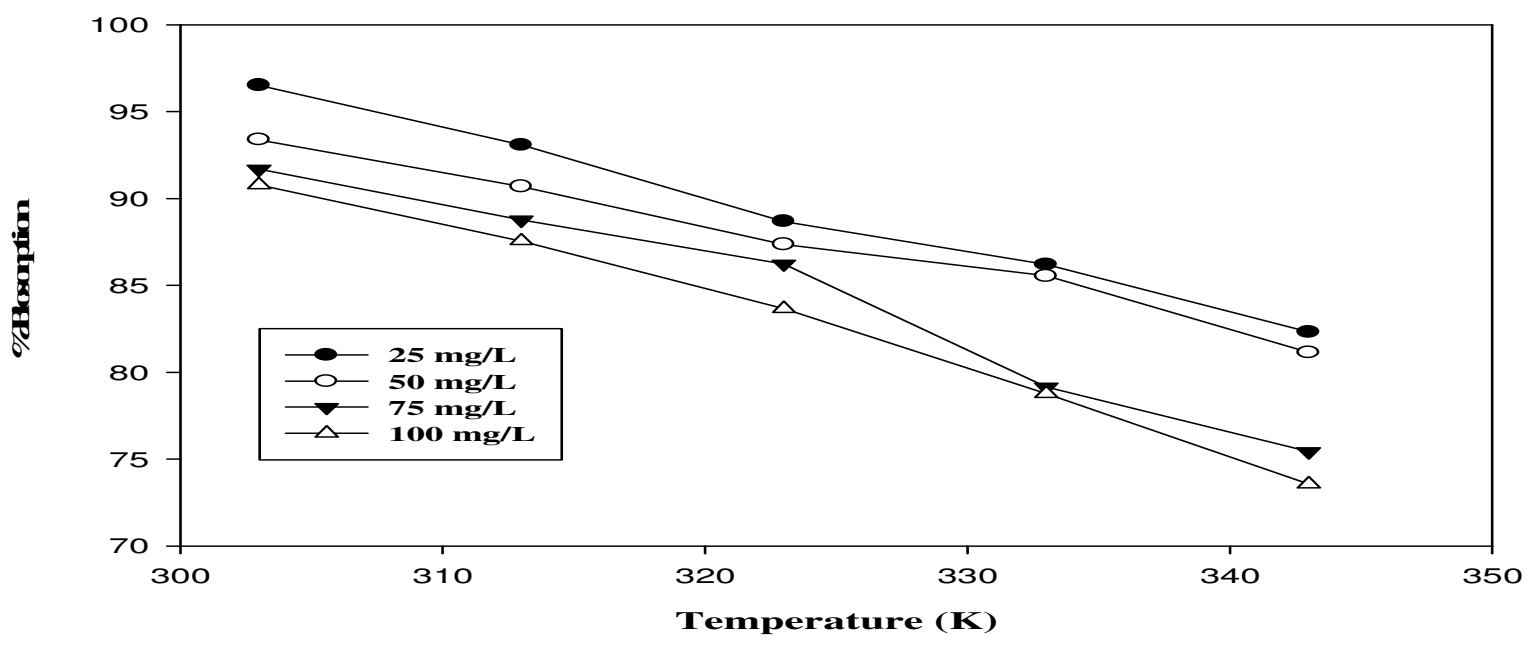

Fig.-6: Effect of temperature on biosorption of MG dye by Plumbago Zeylancia

\section{Equilibrium Isotherm Study}

The isothermal study represents how the biosorption molecules attain a steady state between the liquid and solid phase. For the design purpose, isotherm models were analyzed and suitable model that can fit the data were obtained ${ }^{14}$. Biosorption isotherm is mostly essential to find the interactions of solutes with biosorbents and optimize an effective biosorbent. At various temperatures, isotherm models were favorably adapted to the above system using linear regression analysis.

\section{Langmuir Isotherm}

The Langmuir model assumes a monomolecular layer biosorption having a finite number of vacant sites of constant approach for biosorption with no transmigration of biosorbate in the uniform surface ${ }^{15}$. The equation is: 
RASĀYAN J. Chem.

Vol. 11 | No. 1 |203-218 | January - March | 2018

$\mathrm{C}_{\mathrm{e}} / \mathrm{q}_{\mathrm{e}}=1 / \mathrm{k}_{\mathrm{l}} \mathrm{q}_{\mathrm{m}}+1 / \mathrm{q}_{\mathrm{m}} \mathrm{Ce}$

Where $\mathrm{C}_{\mathrm{e}}$ is a concentration of biosorbate $(\mathrm{mg} / \mathrm{L}), \mathrm{q}_{\mathrm{e}}$ is the quantity of biosorbate adsorbed $(\mathrm{mg} / \mathrm{g}), \mathrm{k}_{\mathrm{l}}$ and $\mathrm{q}_{\mathrm{m}}$ are constants of biosorption rate and biosorption capacity, respectively. $\mathrm{C}_{\mathrm{e}}$ was plotted with $\mathrm{C}_{\mathrm{e}} / \mathrm{q}_{\mathrm{e}}$ representing a Langmuir isotherm with a slope of $1 / \mathrm{q}_{\mathrm{m}}$. The $\mathrm{R}^{2}$ value is 0.9978 at a temperature of $303 \mathrm{~K}$ and $\mathrm{pH}$ of 9.The Langmuir isotherm was fitted for the isotherm data. The Langmuir constants are represented in Table-1 that is calculated from eqn.-3.

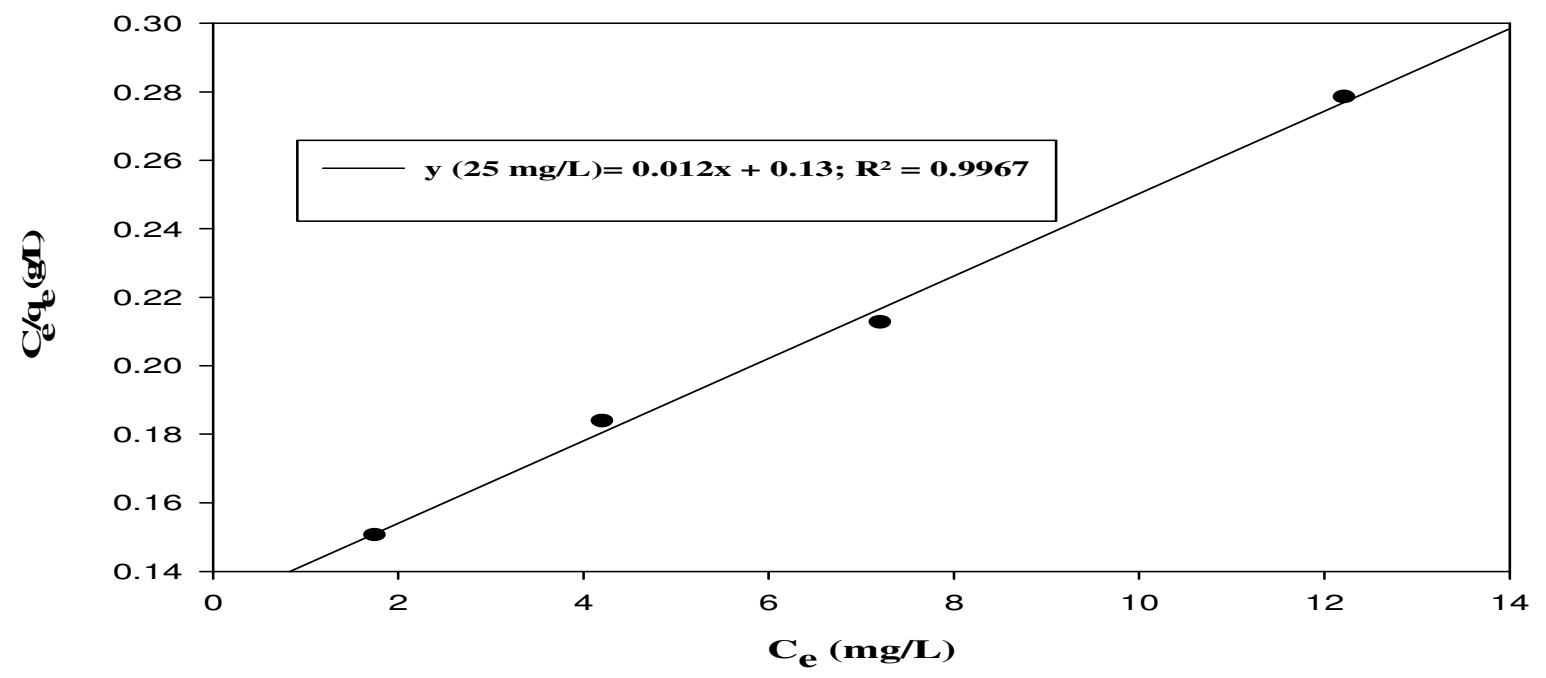

\section{Freundlich Isotherm}

Fig.-7: Langmuir isotherm

The Freundlich isotherm estimates a heterogeneous biosorbing surface and vacant sites with distant energies ${ }^{16}$. The biosorption intensity of a biosorbent was given by this isotherm. The empirical equation is:

$\ln \mathrm{q}_{\mathrm{e}}=\ln \mathrm{K}_{\mathrm{f}}+1 / \mathrm{n} \ln \mathrm{C}_{\mathrm{e}}$

Where, $\mathrm{K}_{\mathrm{f}}$ and $\mathrm{n}$ are Freundlich constants with $\mathrm{n}$ indicating the favorable biosorption process and $\mathrm{K}_{\mathrm{f}}$ $\left((\mathrm{mg} / \mathrm{g})(\mathrm{L} / \mathrm{mg})^{1 / \mathrm{n}}\right)$ the biosorption capacity.

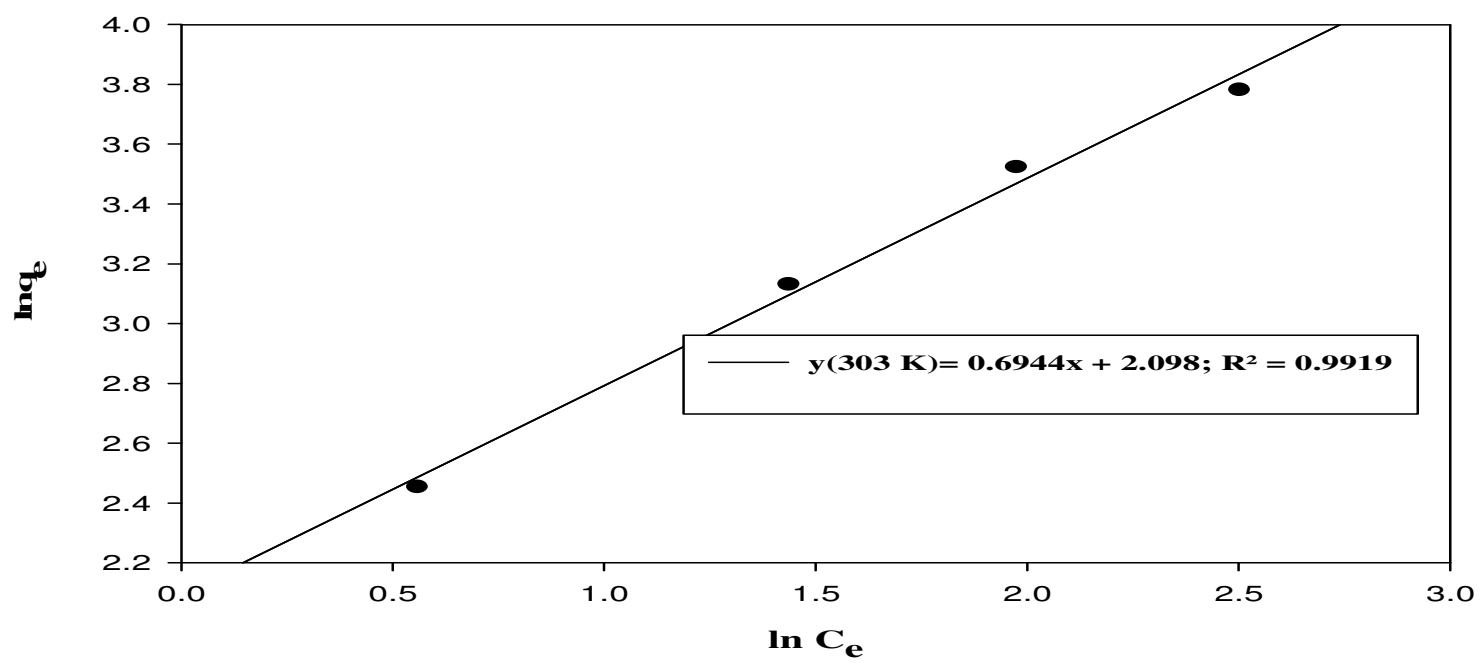

Fig.-8: Freundlich Isotherm 
The plot of $\ln C_{e}$ Versus $\ln q_{e}$ represents Freundlich isotherm. If $1 / n$ is less than unity it represents a Langmuir isotherm, while $1 / \mathrm{n}$ is more than unity represents cooperative biosorption ${ }^{17} . \mathrm{K}_{\mathrm{f}}$ and $\mathrm{n}$ values are evaluated from equation (4) and presented in Table-1.

\section{Temkin isotherm}

Temkin model considers the effect for the indirect biosorbent-biosorbate interaction. The model gives that the heat of biosorption for dye molecules decrease linearly due to interactions ${ }^{18,19}$. The biosorption data is linearly analysed as:

$\mathrm{q}_{\mathrm{e}}=\mathrm{B}_{\mathrm{T}} \ln \left(\mathrm{A}_{\mathrm{T}}\right)+\mathrm{B}_{\mathrm{T}} \ln \left(\mathrm{C}_{\mathrm{e}}\right)$

Where, $\mathrm{A}_{\mathrm{T}}$ and $\mathrm{B}_{\mathrm{T}}$ are the Temkin constants.

$\left.\mathrm{B}_{\mathrm{T}}=\mathrm{RT} / \mathrm{b} ; \mathrm{A}_{\mathrm{T}}=\mathrm{e}^{(\text {intercept/ }} \mathrm{B}_{\mathrm{T}}\right) ;(\mathrm{R}=8.314 \mathrm{~J} / \mathrm{mol} \mathrm{K}), \mathrm{T}$ is the temperature $(\mathrm{K})$.

The Fig.-9 represents the linear plot of $\operatorname{lnC}_{\mathrm{e}}$ vs. $\mathrm{q}_{\mathrm{e}}$ of the Temkin isotherm. The data indicate that constants $\mathrm{B}_{\mathrm{T}}$ and $\mathrm{A}_{\mathrm{T}}$ as 2.49 and 1.59 respectively, $\mathrm{R}^{2}=0.978$ for $\mathrm{MG}$ dye solution that is obtained from equation (5) which are represented in Table-1.

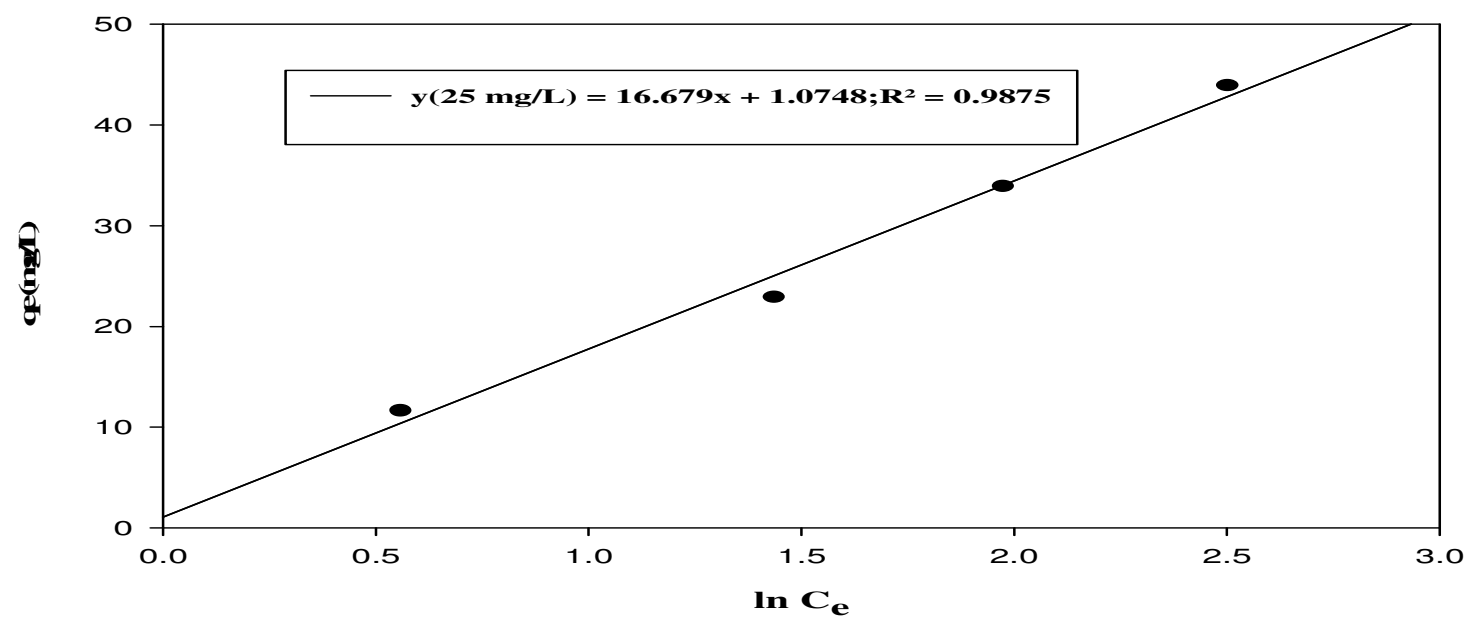

Fig.-9: Temkin isotherm

\section{D-R Isotherm}

The $\mathrm{D}-\mathrm{R}$ isotherm assumes biosorption on a heterogeneous surface ${ }^{20,21}$. The $\mathrm{D}-\mathrm{R}$ isotherm is given by: $\ln \mathrm{q}_{\mathrm{e}}=\ln \mathrm{q}_{\mathrm{o}}-\mathrm{K}_{\mathrm{d}} \varepsilon^{2}$

$\mathrm{K}_{\mathrm{d}}$ is identified from mean free energy $\mathrm{E}, \mathrm{q}_{\mathrm{o}}$ is the infusion capacity and $\varepsilon$ is the Polanyi potential. The mean free energy (E) relates to the change of energy for the solution having one mole of ion shifted to the surface, and was obtained from eqn.-7, as:

$\mathrm{E}=1 / \sqrt{ } 2 \mathrm{~K}_{\mathrm{d}}$

Where $\mathrm{K}_{\mathrm{d}}$ is expressed as the isotherm constant and $\varepsilon$ can be calculated from the equation:

$\varepsilon=\mathrm{RT} \ln \left(1+1 / \mathrm{C}_{\mathrm{e}}\right)$

Where $\mathrm{R}, \mathrm{T}, \mathrm{C}_{\mathrm{e}}$ are gas constant $(8.314 \mathrm{~J} / \mathrm{mol} \mathrm{K})$, the temperature in $\mathrm{K}$ and biosorbate equilibrium concentration, respectively.

\section{Kinetics}

Kinetics of solute uptake is used for optimum conditions of a batch process. The kinetic data was studied using three kinetic models: 
RASĀYAN J. Chem.

Vol. 11 | No. 1 |203-218 | January - March | 2018

\section{Pseudo-First Order Model}

The equation is given as:

$\log \left(\mathrm{q}_{\mathrm{e}}-\mathrm{q}_{\mathrm{t}}\right)=\log \mathrm{q}_{\mathrm{e}}-\left(\mathrm{k}_{\mathrm{l}} / 2.303\right) \times \mathrm{t}$

Where, $\mathrm{k}_{1}$ is the rate constant $\left(\mathrm{min}^{-1}\right)$. A plot was drawn between $\mathrm{t}$ versus $\log \left(\mathrm{q}_{\mathrm{e}}-\mathrm{q}_{\mathrm{t}}\right)$ (Fig.-11) and rate constant value was computed from the eqn.-9 (Table-2).

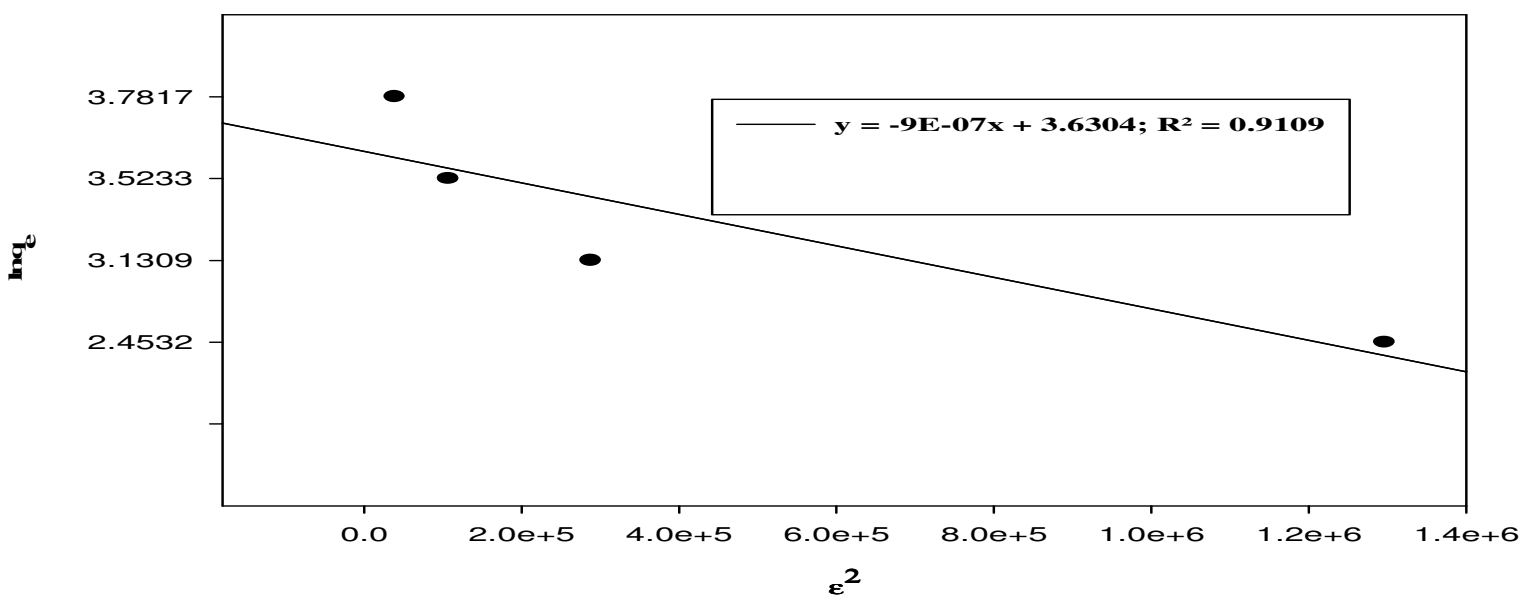

Fig.-10: D-R Isotherm

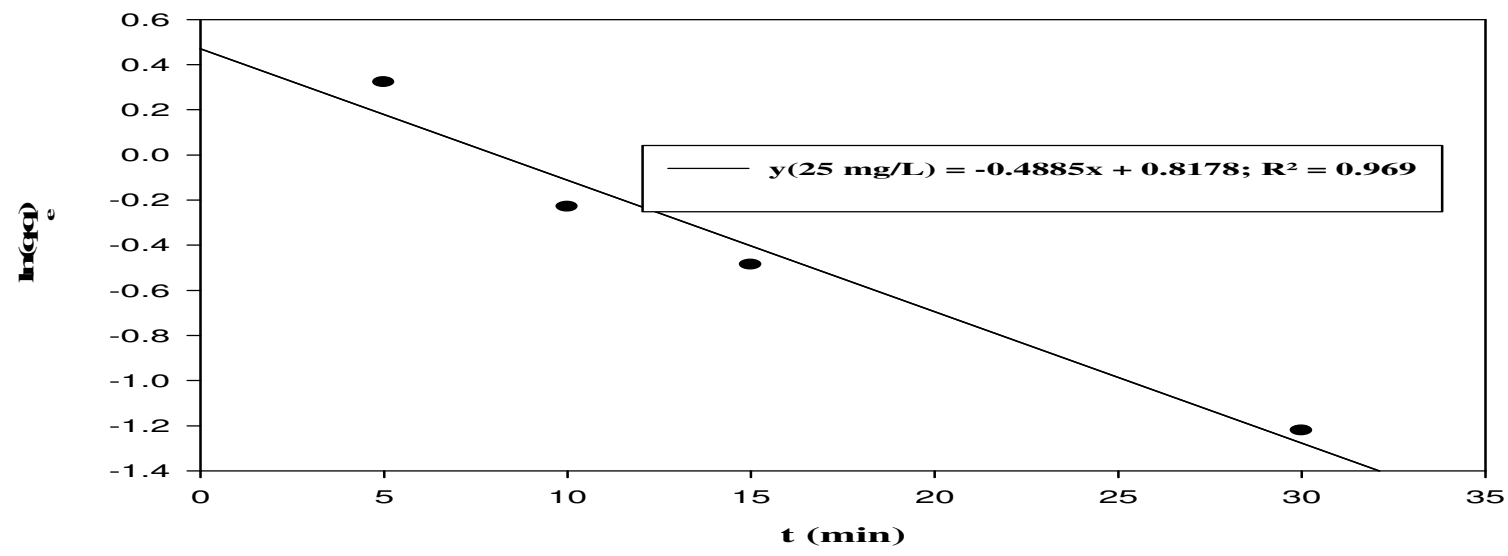

Fig.-11: Pseudo-First Order kinetics

Table-1. Equilibrium constants for MG onto Plumbago Zeylancia

\begin{tabular}{|c|c|c|}
\hline \multicolumn{3}{|c|}{ Langmuir isotherm } \\
\hline $\mathrm{q}_{\mathrm{m}}(\mathrm{mg} / \mathrm{g})$ & $\mathrm{k}_{1}(\mathrm{~L} / \mathrm{mg})$ & $\mathrm{R}^{2}$ \\
\hline 9.1743 & 2.3191 & 0.9967 \\
\hline \multicolumn{3}{|c|}{ Freundlich isotherm } \\
\hline $\mathrm{K}_{\mathrm{f}}(\mathrm{mg} / \mathrm{g})$ & $1 / \mathrm{n}(\mathrm{g} / \mathrm{L})$ & $\mathrm{R}^{2}$ \\
\hline 12.7254 & 6.8119 & 0.9919 \\
\hline \multicolumn{3}{|c|}{ Temkin isotherm } \\
\hline $\mathrm{B}_{\mathrm{T}}(\mathrm{L} / \mathrm{mg})$ & $\mathrm{A}_{\mathrm{T}}(\mathrm{L} / \mathrm{g})$ & $\mathrm{R}^{2}$ \\
\hline $8.904 * 10^{-5}$ & $1.7015^{*} 10^{3}$ & 0.9875 \\
\hline \multicolumn{3}{|l|}{ D-R isotherm } \\
\hline $\mathrm{K}_{\mathrm{d}}\left(\mathrm{mol}^{2} \mathrm{~kJ}^{-2}\right)$ & $\mathrm{q}_{\mathrm{o}}(\mathrm{mg} / \mathrm{g})$ & $\mathrm{R}^{2}$ \\
\hline $1 * 10^{-7}$ & 9.7864 & 0.9109 \\
\hline
\end{tabular}


RASĀYAN J. Chem.

Vol. 11 | No. 1 |203-218 | January - March | 2018

The $\mathrm{R}^{2}$ value was 0.9036 for $25 \mathrm{mg} / \mathrm{L}$ of dye concentration. The pseudo-first-order kinetic model is mostly predicted for dye biosorption kinetics.

\section{Pseudo-Second Order Model}

The pseudo second order model was:

$\mathrm{t} / \mathrm{q}_{\mathrm{t}}=1 / \mathrm{k}_{2} \mathrm{qe}^{2}+1 \times \mathrm{t} / \mathrm{q}_{\mathrm{e}}$

Where, $\mathrm{q}_{\mathrm{e}}$ the biosorption capacity $(\mathrm{mg} / \mathrm{g}), \mathrm{k}_{2}$ is the rate constant of $(\mathrm{g} / \mathrm{mg} \min )$. The plot of $\mathrm{t} v \mathrm{vs}$. $\mathrm{t} / \mathrm{q}_{\mathrm{t}}$ is shown in Fig.-12 yield a $\mathrm{R}^{2}$ value of 0.999 for $25 \mathrm{mg} / \mathrm{L}$ of dye concentration. The value of rate constant $\mathrm{k}_{2}$ was calculated from the eqn.-10, which is presented in Table- 2 .

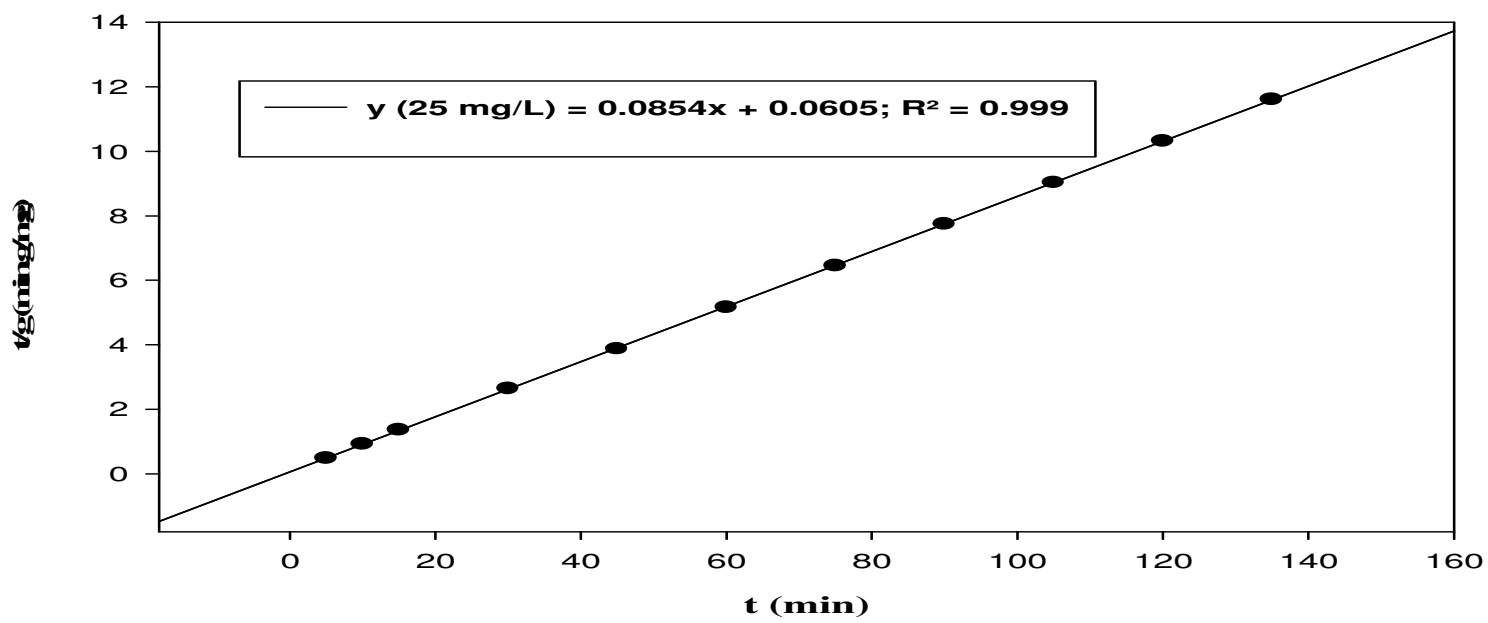

\section{Elovich Kinetic Model}

Fig.-12: Pseudo-Second Order Kinetics

Elovich model gives about the type of adsorption mechanism and second-order kinetics of chemisorption. The elovich or Roginsky-Zeldovich equation is:

$\mathrm{dq}_{\mathrm{t}} / \mathrm{dt}=\alpha \exp \left(-\gamma \mathrm{q}_{\mathrm{t}}\right)$

Where, $\alpha$ is the MG sorption rate of coverage $[\mathrm{mmol} /(\mathrm{g} \min )]$ and $\gamma$ is the activation energy $(\mathrm{g} / \mathrm{mmol})$.

The elovich equation is simplified as:

$\mathrm{q}=1 / \gamma \ln (\alpha \gamma)+1 / \gamma \ln \mathrm{t}$

A linear plot of $\ln t$ versus $\mathrm{q}_{\mathrm{t}}$ is drawn where the values $\alpha$ and $\gamma$ can be computed from eqn.-12. $\mathrm{R}^{2}$ is 0.891 (presented in Table-2). The value of $\mathrm{R}^{2}$ is low, which indicates the non-applicability of Elovich model to the experimental data.

Table-2. Kinetics constants for Malachite green onto Plumbago Zeylanci

\begin{tabular}{c|c|c|c|c|c|c|c|c|c}
\hline \multirow{2}{*}{$\begin{array}{c}\text { Dye } \\
\text { Concentration }\end{array}$} & \multicolumn{3}{|c|}{ Pseudo First Order } & \multicolumn{3}{c|}{ Pseudo Second Order Kinetics } & \multicolumn{3}{c}{ Elovich Model } \\
\cline { 2 - 10 } & $\begin{array}{c}\mathrm{k}_{1} \\
\left(\mathrm{~min}^{-1}\right)\end{array}$ & $\begin{array}{c}\mathrm{q}_{\mathrm{e}} \\
(\mathrm{mg} / \mathrm{g})\end{array}$ & $\mathrm{R}^{2}$ & $\begin{array}{c}\mathrm{k}_{2} \\
(\mathrm{~g} / \mathrm{mg} \cdot \mathrm{min})\end{array}$ & $\begin{array}{c}\mathrm{q}_{\mathrm{e}, \mathrm{cal}} \\
(\mathrm{mg} / \mathrm{g})\end{array}$ & $\mathrm{R}^{2}$ & $\begin{array}{c}\gamma \\
(\mathrm{g} / \mathrm{mg})\end{array}$ & $\begin{array}{c}\alpha \\
(\mathrm{mg} / \mathrm{g} . \mathrm{min})\end{array}$ & $\mathrm{R}^{2}$ \\
\hline $\begin{array}{c}\text { Malachite } \\
\text { green -25 } \\
\mathrm{mg} / \mathrm{L}\end{array}$ & 1.1250 & 2.635 & 0.969 & 0.1205 & 11.70 & 0.999 & 2.52 & $2.525 \times 10^{10}$ & 0.891 \\
\hline
\end{tabular}


RASĀYAN J. Chem.

Vol. 11 | No. 1 |203-218 | January - March | 2018

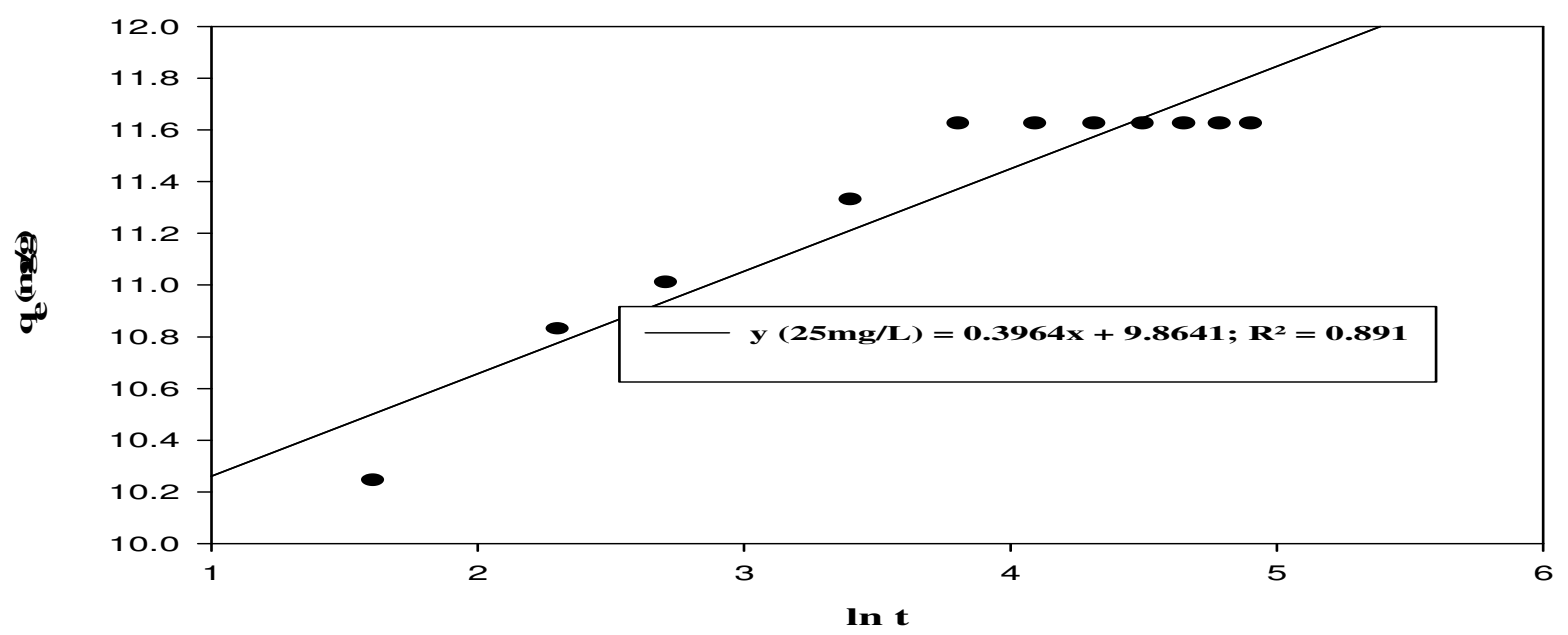

Fig.-13: Elovich Kinetics Model

Thermodynamic Studies

The effectiveness of the biosorption is given by thermodynamic studies. The Van't Hoff equation is:

$\ln K_{D}=\Delta S^{\circ} / R-\Delta H^{\circ} / R T$

Where, standard enthalpy $\left(\Delta \mathrm{H}^{\circ}\right)$, standard entropy $\left(\Delta \mathrm{S}^{\circ}\right)$ and Gibbs free energy $\left(\Delta \mathrm{G}^{\circ}\right), \mathrm{K}_{\mathrm{D}}$ is constant, $(\mathrm{R}=8.314 \mathrm{~J} / \mathrm{mol} \mathrm{K})$ and $\mathrm{T}$ is the temperature $(\mathrm{K})$. The $\Delta \mathrm{H}^{\circ}$ and $\Delta \mathrm{S}^{\mathrm{o}}$ were enumerated from the linear Van't Hoff plot i.e. ln $K_{D}$ vs. 1/T and computed using the eqn.-13.

$\Delta \mathrm{G}^{\mathrm{o}}=-\mathrm{RT} \ln \mathrm{K}_{\mathrm{D}}$

The $\Delta \mathrm{G}^{\mathrm{o}}$ is calculated from eqn.-14. The negative values of $\Delta \mathrm{G}^{\mathrm{o}}$ represent the biosorption as simple and feasible. With a raise in temperature the negative values of $\Delta \mathrm{G}^{\circ}$ decreases, shows that reduction in the feasibility of biosorption.

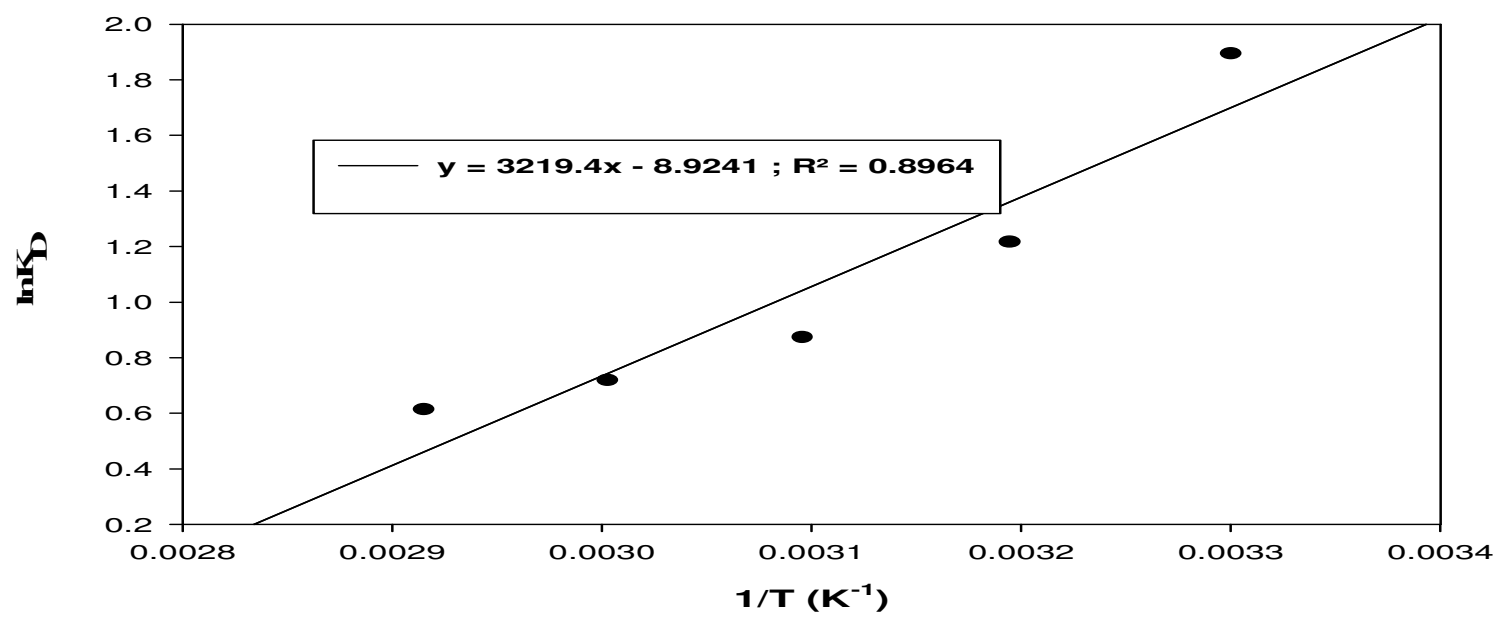

Fig.-14: Thermodynamic studies

The negative values of $\Delta \mathrm{G}^{\mathrm{o}},-5.55$ to $-2.75 \mathrm{~kJ} / \mathrm{mol}$ which indicates that physisorption is dominating the weak chemical interactions. The negative value of $\Delta \mathrm{H}^{0}$ represents biosorption mechanism to be exothermic, which represents the fact that the energy used for bond splitting is less than the energy used 
for bond making between the dye and the biosorbent. The decline in randomness between the solid-solute interface represents the negative value of $\Delta \mathrm{S}^{\circ}$. Table-3 shows the thermodynamic parameters.

Table-3: Values of Thermodynamic parameters

\begin{tabular}{c|c|c|c}
\hline Temperature (K) & \multicolumn{3}{|c}{ Malachite Green } \\
\hline & $\begin{array}{c}\Delta \mathrm{G}^{0} \\
(\mathrm{~kJ} / \mathrm{mol})\end{array}$ & $\begin{array}{c}\Delta \mathrm{H}^{0} \\
(\mathrm{~kJ} / \mathrm{mol})\end{array}$ & $\Delta \mathrm{S}^{0}(\mathrm{~kJ} / \mathrm{mol})$ \\
\hline 303 & -5.55 & & \\
\cline { 1 - 2 } 313 & -4.85 & & \\
\cline { 1 - 2 } 323 & -4.15 & \multirow{2}{*}{-26.76} & -0.07 \\
\cline { 1 - 2 } 333 & -3.45 & & \\
\cline { 1 - 2 } 343 & -2.75 & & \\
\hline
\end{tabular}

\section{Response Surface Methodology (RSM)}

The utilization of RSM for the assessment of parameters represents an empirical relation between the response and the variables along with percentage biosorption by applying CCD. A CCD with 26 experiments was conducted ( 16 cube point runs, 8 center point runs and 2 axial point runs).Optimization studies were computed by different parameters including time, $\mathrm{pH}$, dye concentration, temperature. The variables used as a part of the study were coded by using:

$\mathrm{x}_{1}=\mathrm{X}_{1}-\mathrm{X}_{0} / \Delta \mathrm{X}$

In this manner, CCD with four variables is employed with STATISTICA 6.0 with the optimum conditions having time $=5$ to $135 \mathrm{~min}, \mathrm{pH}=2$ to 10 , dye concentration $=25$ to $100 \mathrm{mg} / \mathrm{L}$, temperature $=303$ to $343 \mathrm{~K}$ as in Table-4.

Table-4: Process Variables and their levels

\begin{tabular}{c|c|c|c|c|c|c|c}
\hline Factors & Name & Units & -2 & -1 & 0 & 1 & 2 \\
\hline $\mathrm{X}_{1}$ & Contact time & $\mathrm{min}$ & 35 & 40 & 45 & 50 & 55 \\
\hline $\mathrm{X}_{2}$ & Solution $\mathrm{pH}$ & & 5 & 7 & 9 & 11 & 13 \\
\hline $\mathrm{X}_{3}$ & $\begin{array}{c}\text { Initial dye } \\
\text { concentration }\end{array}$ & $\mathrm{mg} / \mathrm{L}$ & 15 & 20 & 25 & 30 & 35 \\
\hline $\mathrm{X}_{4}$ & Temperature & $\mathrm{K}$ & 293 & 298 & 303 & 308 & 313 \\
\hline
\end{tabular}

The study includes the use of CCD to optimize the biosorption so as to fit for process optimization. The chosen variables were acquired by obtaining an equation for process parameters with optimization criteria.

\section{Finding the Data using the CCD Model}

Analysis of variance (ANOVA) used to obtain the statistical significance ${ }^{22}$ for the MB dye using PZ biosorbent was illustrated by a quadratic model. The values of the experimental model and their statistical analyses were calculated by Design Expert Software, presented in Table-5.

Table-5: ANOVA for the biosorption of MG

\begin{tabular}{|llllll|}
\hline Source & $\mathrm{SS}$ & Df & Mass Square & F-value & the p-value \\
$\mathrm{X}_{1}$ & 1.40167 & 1 & 1.40167 & 36.5291 & 0.000084 \\
$\mathrm{X}_{1}{ }^{2}$ & 18.29348 & 1 & 18.29348 & 476.7502 & 0.000000 \\
$\mathrm{X}_{2}$ & 2.00682 & 1 & 2.00682 & 52.3001 & 0.000017 \\
\hline
\end{tabular}


RASĀYAN J. Chem.

Vol. 11 | No. 1 |203-218 | January - March | 2018

\begin{tabular}{|llllll||}
$\mathrm{X}_{2}{ }^{2}$ & 12.68520 & 1 & 12.68520 & 330.5916 & 0.000000 \\
$\mathrm{X}_{3}$ & 1.40167 & 1 & 1.40167 & 36.5291 & 0.000084 \\
$\mathrm{X}_{3}{ }^{2}$ & 5.13698 & 1 & 5.13698 & 133.8759 & 0.000000 \\
$\mathrm{X}_{4}$ & 0.74202 & 1 & 0.74202 & 19.3378 & 0.001068 \\
$\mathrm{X}_{4}{ }^{2}$ & 2.45455 & 1 & 2.45455 & 63.9684 & 0.000007 \\
$\mathrm{X}_{1} \mathrm{X}_{2}$ & 0.39062 & 1 & 0.39062 & 10.1802 & 0.008597 \\
$\mathrm{X}_{1} \mathrm{X}_{3}$ & 1.48840 & 1 & 1.48840 & 38.7895 & 0.000065 \\
$\mathrm{X}_{1} \mathrm{X}_{4}$ & 1.28822 & 1 & 1.28822 & 33.5727 & 0.000120 \\
$\mathrm{X}_{2} \mathrm{X}_{3}$ & 13.91290 & 1 & 13.91290 & 362.5869 & 0.000000 \\
$\mathrm{X}_{2} \mathrm{X}_{4}$ & 5.78402 & 1 & 5.78402 & 150.7387 & 0.000000 \\
$\mathrm{X}_{3} \mathrm{X}_{4}$ & 0.04000 & 1 & 0.04000 & 1.0424 & 0.329183 \\
$\mathrm{X}_{1}$ & 0.42208 & 11 & 0.03837 & & \\
$\mathrm{X}_{1}{ }^{2}$ & 51.55947 & 25 & $\mathrm{R}-\mathrm{sqr}=.99181 ; \mathrm{R}^{2}(\mathrm{Adj})=98.139$ & \\
\hline
\end{tabular}

Df: degree of freedom, SS: sum of squares, F: factor, $\mathrm{P}=$ probability

The second order polynomial equation:

$\%$ Removal $(\mathrm{Y})=-1431.74-0.25 \mathrm{X}_{1}+23.83 \mathrm{X}_{2}+1.93 \mathrm{X}_{3}+9.21 \mathrm{X}_{4}-0.04 \mathrm{X}_{1}^{2}-0.21 \mathrm{X}_{2}^{2}-0.02 \mathrm{X}_{3}^{2}-$ $0.02 \mathrm{X}_{4}^{2}+0.002 \mathrm{X}_{1} \mathrm{X}_{2}+0.01 \mathrm{X}_{1} \mathrm{X}_{3}+0.001 \mathrm{X}_{1} \mathrm{X}_{4}-0.09 \mathrm{X}_{2} \mathrm{X}_{3}-0.06 \mathrm{X}_{2} \mathrm{X}_{4}-0.00 \mathrm{X}_{3} \mathrm{X}_{4}$

From eqn-16 $\mathrm{Y}$ is the $\%$ removal, $\mathrm{X}_{1}, \mathrm{X}_{2}, \mathrm{X}_{3}$ and $\mathrm{X}_{4}$ are the coded values of independent variables such as time, $\mathrm{pH}$, dye concentration and temperature. The t-value and $\mathrm{p}$-values are tabulated in Table-6.The important parameters were determined via p-values and the t-test.

Table-6: Regression Coefficient Values

\begin{tabular}{||l|l|l|l|l|}
\hline & Regression coefficients & SE coefficient & $t$-value & p-value \\
\hline Constant. & -1431.74 & 178.0186 & -8.0426 & 0.000006 \\
\hline $\mathrm{X}_{1}$ & -0.25 & 0.6206 & -0.3988 & 0.697670 \\
\hline $\mathrm{X}_{1}{ }^{2}$ & -0.04 & 0.0019 & -21.8346 & 0.000000 \\
\hline $\mathrm{X}_{2}$ & 23.83 & 1.5199 & 15.6761 & 0.000000 \\
\hline $\mathrm{X}_{2}{ }^{2}$ & -0.21 & 0.0117 & -18.1822 & 0.000000 \\
\hline $\mathrm{X}_{3}$ & 1.93 & 0.6090 & 3.1740 & 0.008855 \\
\hline $\mathrm{X}_{3}{ }^{2}$ & -0.02 & 0.0019 & -11.5705 & 0.000000 \\
\hline $\mathrm{X}_{4}$ & 9.21 & 1.1419 & 8.0618 & 0.000006 \\
\hline $\mathrm{X}_{4}{ }^{2}$ & -0.02 & 0.0019 & -7.9980 & 0.000007 \\
\hline $\mathrm{X}_{1} \mathrm{X}_{2}$ & 0.02 & 0.0049 & 3.1906 & 0.008597 \\
\hline $\mathrm{X}_{1} \mathrm{X}_{3}$ & 0.01 & 0.0020 & 6.2281 & 0.000065 \\
\hline $\mathrm{X}_{1} \mathrm{X}_{4}$ & 0.01 & 0.0020 & 5.7942 & 0.000120 \\
\hline
\end{tabular}


RASĀYAN J. Chem.

Vol. 11 | No. 1 |203-218 | January - March | 2018

\begin{tabular}{|l|l|l|l|l|}
\hline $\mathrm{X}_{2} \mathrm{X}_{3}$ & -0.09 & 0.0049 & -19.0417 & 0.000000 \\
\hline $\mathrm{X}_{2} \mathrm{X}_{4}$ & -0.06 & 0.0049 & -12.2776 & 0.000000 \\
\hline $\mathrm{X}_{3} \mathrm{X}_{4}$ & -0.00 & 0.0020 & -1.0210 & 0.329183 \\
\hline
\end{tabular}

A t-value and smaller p-value identify the effect that appears ${ }^{23,24}$. The first order variables, namely contact time $\left(\mathrm{X}_{1}\right)$, solution $\mathrm{pH}\left(\mathrm{X}_{2}\right)$, initial dye concentration $\left(\mathrm{X}_{3}\right)$ and temperature $\left(\mathrm{X}_{4}\right)$ their second order main effects $\mathrm{X}_{2} \mathrm{X}_{3}, \mathrm{X}_{2} \mathrm{X}_{4}$ and $\mathrm{X}_{3} \mathrm{X}_{4}$ are important as p-values are very small to be considered. This denotes that the first order and second order variables are mostly evident from their corresponding $\mathrm{p}$-values. The quantities $\mathrm{X}_{2}, \mathrm{X}_{3}$ and $\mathrm{X}_{4}$ have a positive influence while $\mathrm{X}_{2} \mathrm{X}_{3}, \mathrm{X}_{2} \mathrm{X}_{4}$ etc. shows a negative influence on biosorption. The second order polynomial equation is fitted by ANOVA analysis. The ANOVA equation represents adequately the actual relation between the response and the significant variables. The determination coefficient $\left(\mathrm{R}^{2}\right)$ was $93.2 \%$ which is high and has advocated high effect on the experimental and the predicted value. Table-7 represents experimental values vs. predicted values of the present study. A plot representing experimental values vs. predicted values is shown in Fig.-15.

Table-7: The Experimental values vs. Predicted values for biosorption of MB dye

\begin{tabular}{|c|c|c|}
\hline S.No. & Experimental values of biosorption & Predicted values of biosorption \\
\hline 1 & 89.43 & 89.38 \\
\hline 2 & 90.59 & 90.47 \\
\hline 3 & 90.14 & 90.25 \\
\hline 4 & 90.87 & 91.14 \\
\hline 5 & 92.63 & 92.71 \\
\hline 6 & 91.37 & 91.40 \\
\hline 7 & 89.98 & 89.86 \\
\hline 8 & 88.42 & 88.34 \\
\hline 9 & 87.41 & 87.41 \\
\hline 10 & 89.37 & 89.63 \\
\hline 11 & 89.39 & 89.50 \\
\hline 12 & 91.69 & 91.52 \\
\hline 13 & 91.5 & 91.37 \\
\hline 14 & 91.38 & 91.18 \\
\hline 15 & 89.69 & 89.73 \\
\hline 16 & 89.16 & 89.34 \\
\hline 17 & 89.43 & 89.38 \\
\hline 18 & 88.45 & 88.42 \\
\hline 19 & 89.2 & 89.01 \\
\hline 20 & 90.05 & 90.16 \\
\hline 21 & 91.23 & 91.31 \\
\hline 22 & 90.5 & 90.34 \\
\hline 23 & 91.15 & 91.14 \\
\hline 24 & 91.92 & 91.85 \\
\hline 25 & 93 & 93.00 \\
\hline 26 & 93 & 93.00 \\
\hline
\end{tabular}




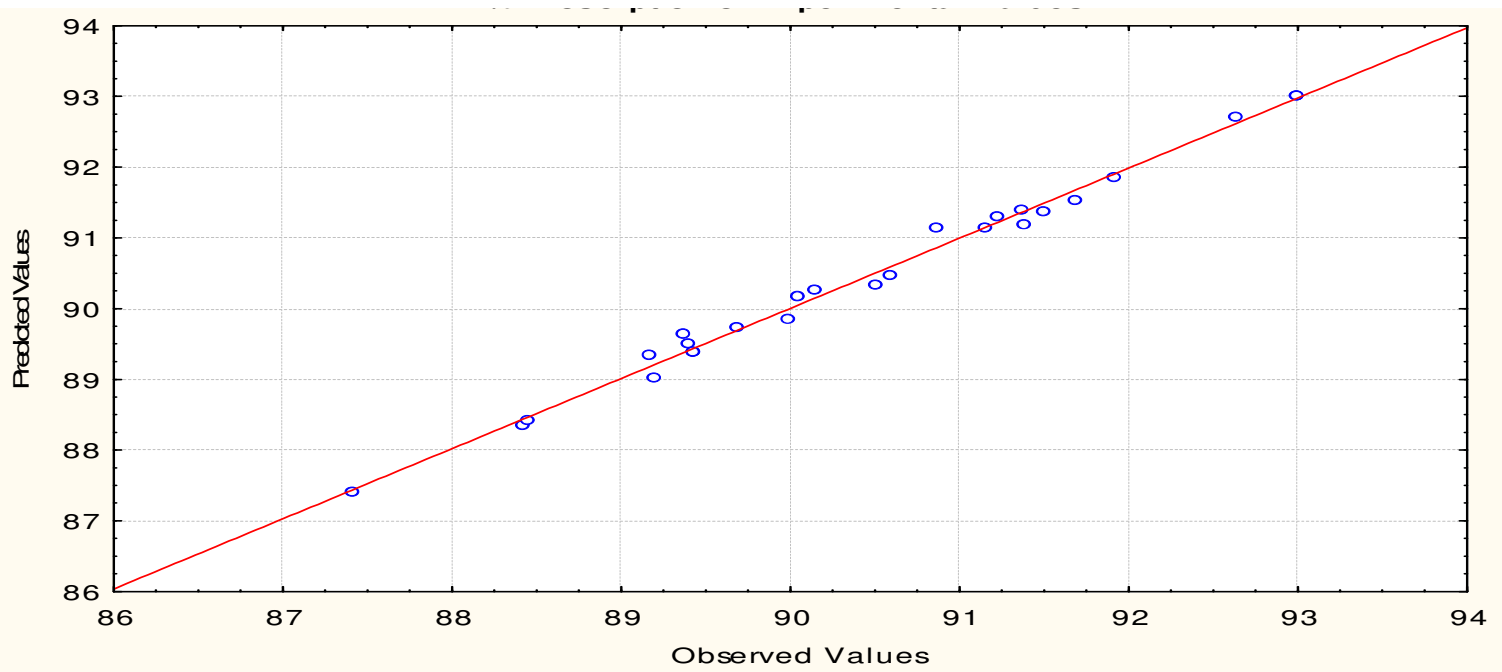

Fig.-15: Correlation plot of experimental values vs. predicted values

\section{Interaction Effects and Optimization by Response Surface Modeling}

The \%biosorption of MB dye with an appropriate combination of free variables through a dimensional perspective of response surface plots are shown in Figs-16 to 21. All the response surface plots are drawn at low and high levels values of the variables. The curved shape of the surface plots represents the optimal of the variables such as time, $\mathrm{pH}$, dye concentration and temperature.

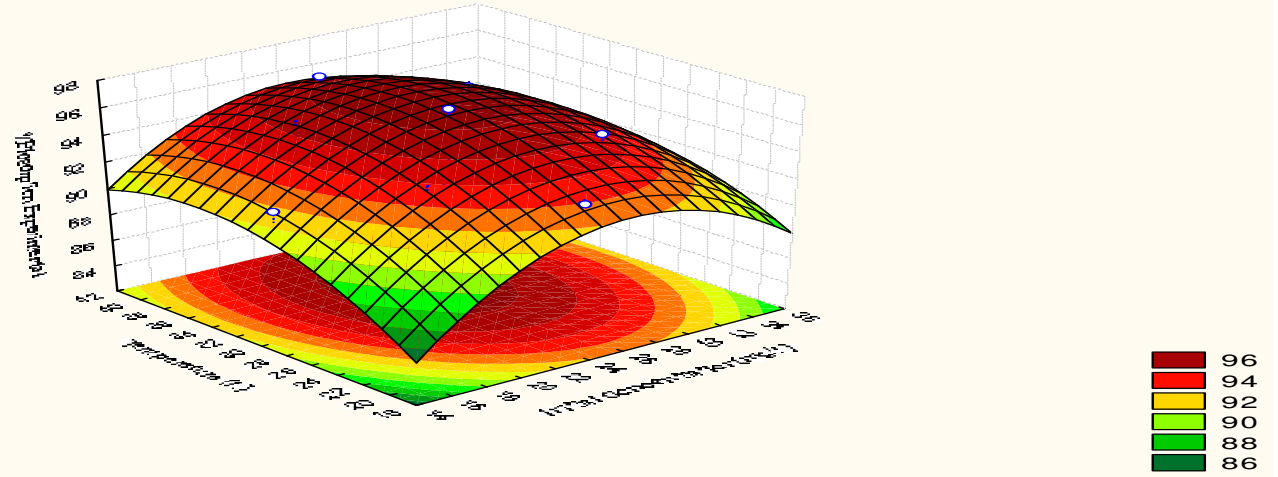

Fig.-16: Response surface plot of dye concentration vs. temperature for the biosorption of MG.

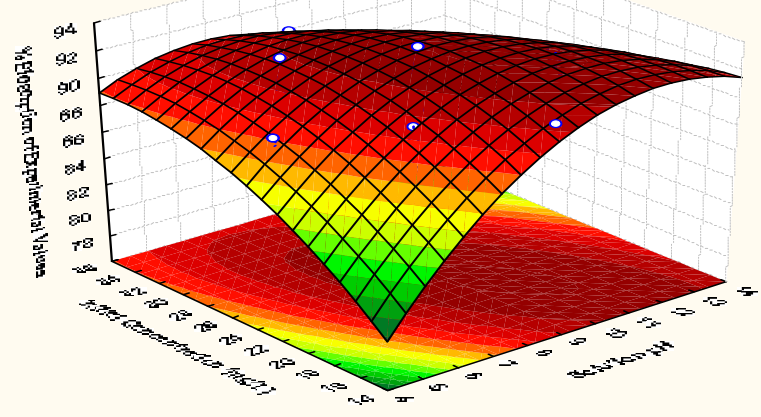

Fig.-17: Response surface plot of $\mathrm{pH}$ vs. dye concentration for the biosorption of MG. 
RASĀYAN J. Chem.

Vol. 11 | No. 1 |203-218 | January - March | 2018

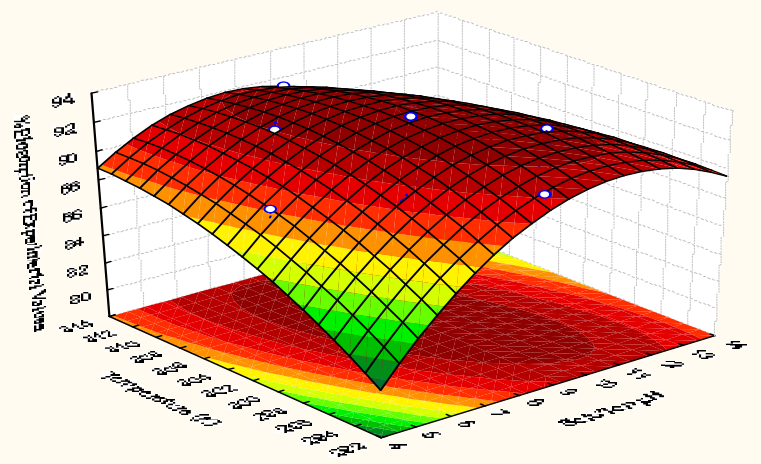

Fig.-18: Response surface plot of $\mathrm{pH}$ vs. temperature for the biosorption of Malachite green.

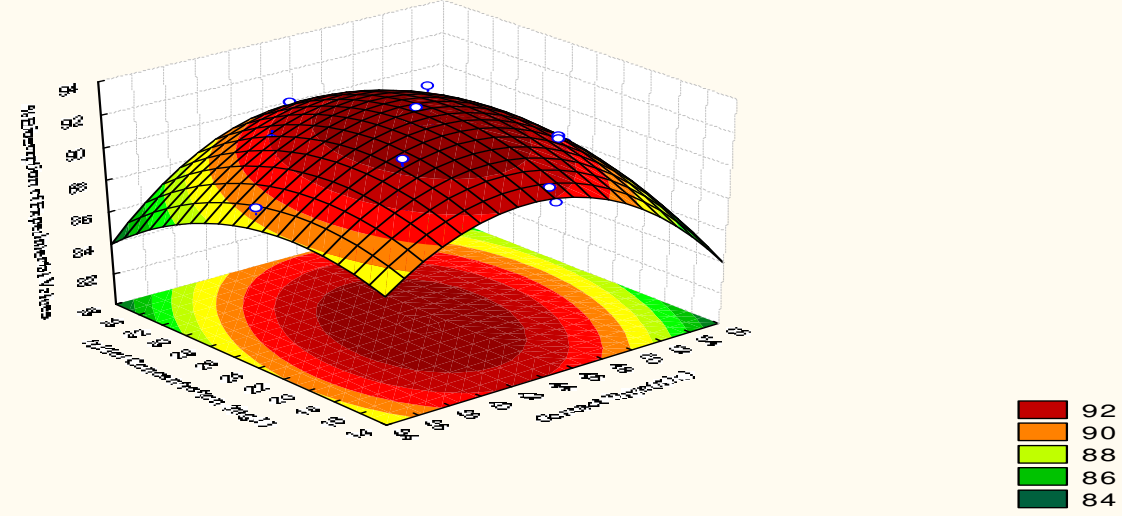

Fig.-19: Response surface plot of time vs. dye concentration for the biosorption of MG .

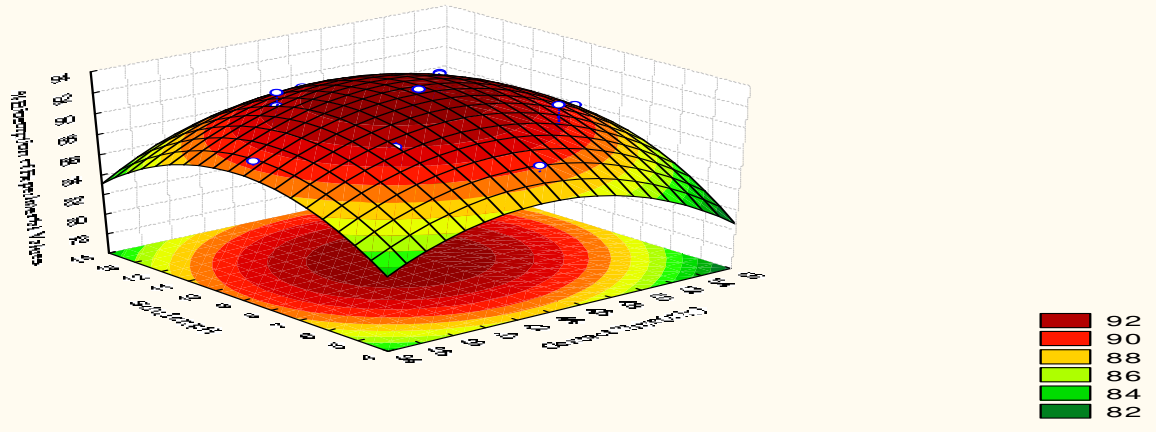

Fig.-20: Response surface plot of time vs. $\mathrm{pH}$ for the biosorption of MG.

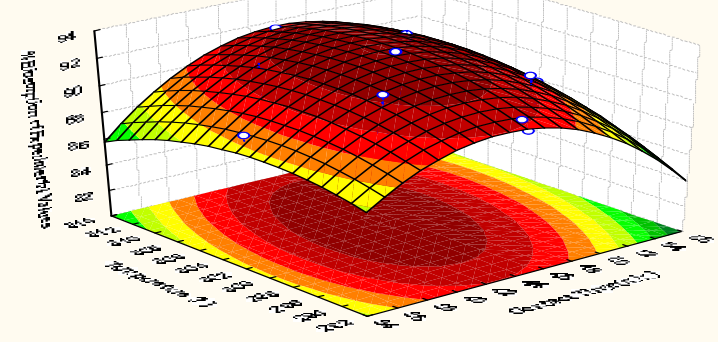

Fig.-21: Response surface plot of time vs. temperature for the biosorption of MG. 
RASĀYAN J. Chem.

Vol. 11 | No. 1 |203-218 | January - March | 2018

A moderately solid interaction was seen in all the graphs comparing p- values individually. The enhanced biosorption conditions set for the biosorbent $\mathrm{PZ}$ are contact time of $43.6 \mathrm{~min}, \mathrm{pH} \mathrm{10.8}$, dye concentration of $19.7 \mathrm{mg} / \mathrm{L}$ and at a temperature of $300.3 \mathrm{~K}$ having $93.2 \%$ of biosorption

\section{CONCLUSION}

- The analyses were executed as components of contact time, $\mathrm{pH}$, dye concentration, biosorbent dosage, average biosorbent size and temperature.

- Langmuir model best fit the isotherm data.

- Psuedo second order kinetics followed the kinetic values.

- The negative value of $\Delta \mathrm{H}^{0}$ reveals the reaction is exothermic, $\Delta \mathrm{G}^{0}$ reveals the process is feasible and spontaneity and $\Delta \mathrm{S}^{0}$ give the randomness of the reaction.

- The acquired conclusions represent biosorption potential of Plumbago Zeylancia is a better absorbing medium for MG dye and has high bisorption yields.

- In case of experimental biosorption, the \% removal is $93 \%$ of MG dye biosorption at a time of $45 \mathrm{~min}$, $\mathrm{pH}$ of 9 , the dye concentration of $25 \mathrm{mg} / \mathrm{L}$ and temperature of $303 \mathrm{~K}$.

- The perception of Plumbago Zeylancia biomass is best suitable for the biosorption of MG dye as the RSM conclude that the values of the process variables are an MB concentration of $19.7 \mathrm{mg} / \mathrm{L}, \mathrm{pH}$ of 10.8 , at a temperature of $300.3 \mathrm{~K}$ with a time of $43.6 \mathrm{~min}$ having a \% biosorption as 93.24.

\section{REFERENCES}

1. K.K., M. Talat and S.H. Hal., Sin., Bioresource Technology, 97(16), 2124(2006).

2. Taty-Cost., V.C., H. Faud., C. Por., and A. Delac., J. of Hazardous Mater., 105(1-3), 121(2003).

3. P. LeCloirec, Redd., Z., C. Gere., Y. Andres, Environmental Science Technology, 36 (9), 2067 (2002).

4. Vijayarag., K., K. Palan., and M. Vel., Bioresource Technology,97 (12), 1411 (2005).

5. Kwe., D.K., J.K. Choi, E.K. Kim and S.T. Lim, Carbohydrate Polymers, 46(2), $171(2001)$.

6. Kum., U. and M. Bandyopadhyay, Bioresource Technology, 97(1), 104 (2006).

7. M.H. Kalavathy, L.R.Miranda, Desalination, 255(1-3), 165 (2010).

8. I.D. Mal., I.M. Mish., V.C. Srivastava, Colloids Surf A: Physicochemical Colloids Surface Physicochemical Engg., Asp., 312(2-3), 172 (2008).

9. B. Yasem., A. Hal., Desalination, 194 (1-3), 259 (2006).

10. Mansoor Anbia, Saba Asl Hariri, Desalination, 261 (1-3), 61 (2010).

11. T. Santhi, S. Manonman, T.Smita and K. Mahalakshmi, Rasayan Journal of Chem., 2 (4), 813 (2009).

12. Kalpana P., King P., International J., of Sci., \& Engineering Reser., 4(4), 1244 (2013).

13. P.Kalpana, V.Omkar, P.King, Chemical Technology: An Indian Journal, 11(2), 43 (2016).

14. Dhakal, R.P., K.N. Ghimire, K. Inoue, M. Yano and K. Makino, Separation Purification Technology, 42(3), 219 (2005).

15. S.Wang, Z.H.Zhu, A.Coomes. F.Haghseresht, G.Q.Lu, J. of Coll. Interface Sci., 284 (2), 440 (2005).

16. P.Kalpana, P.King, International J. of Wastewater Treat., and Green Chem., 6 (3), 159 (2011).

17. G.Kalyani, P.King, Y.Prasanna Kumar, Rasayan Journal of Chem., 9(3), 510 (2016).

18. I.A.W.Tan, A.L.Ahmad, B.H.Hameed, Desalination, 225 (1-3), 13(2008).

19. P.Ahuja, R.Gupta, R.K.Saxena, Process Biochem., 34, 218(2006).

20. S.Qaiser, R.Anwar, Saleemi, M.MuhammadUmar, Electronic Journal and Biotechnology, 12(4), 2225(2009).

21. A.G El-Said, Journal of American Science, 6(10), 143 (2010).

22. K.G.Bhattacharyya, A.Sharma, J. of Hazardous Mater. (B), 113 (1-2), 97 (2004).

23. K.V.Kumar, A.Kumaran, Biochem.Eng.J. ,27, 83 (2005).

24. H.Joga Rao, P.King, Y.Prasanna Kumar, Rasayan Journal of Chem., 9 (2), 254 (2016).

[RJC-1971/2017] 